\title{
IMÁGENES EN MEDICINA
}

\section{GLOMERULONEFRITIS}

\author{
Claudia Peña*
}

\section{HISTORIA CLÍNICA}

Paciente de sexo femenino y 38 años de edad con impresión diagnóstica de síndromes nefrítico y nefrótico asociados con lupus eritematoso sistémico y anemia hemolítica, diagnosticados hace ocho meses y que se encuentra en tratamiento con prednisona $5 \mathrm{mg} / \mathrm{d}$ áa, calcio $600 \mathrm{mg} /$ día, y ácido acetil salicílico I (0) mg/día. No presenta antecedentes patológicos de importancia, excepto los familiares, con una hermana con lupus eritematoso sistémico.

Es atendida en el servicio de nefrología y se encuentra hipertensión arterial al examen físico. Los exámenes paraclínicos de importancia fueron:

Nitrógeno ureico: $15 \mathrm{mg} / \mathrm{dl}(6-20 \mathrm{mg} / \mathrm{dl})$, creatinina: $1,08 \mathrm{mg} / \mathrm{dl}(0,5-0,9 \mathrm{mg} / \mathrm{dl})$, depuración de creatinina: $66 \mathrm{ml} / \mathrm{minuto}(60-120 \mathrm{ml} / \mathrm{min}$ ), volumen de diuresis: $2.330 \mathrm{ml}$ en 24 horas, proteinuria: $543 \mathrm{mg} / 24$ horas

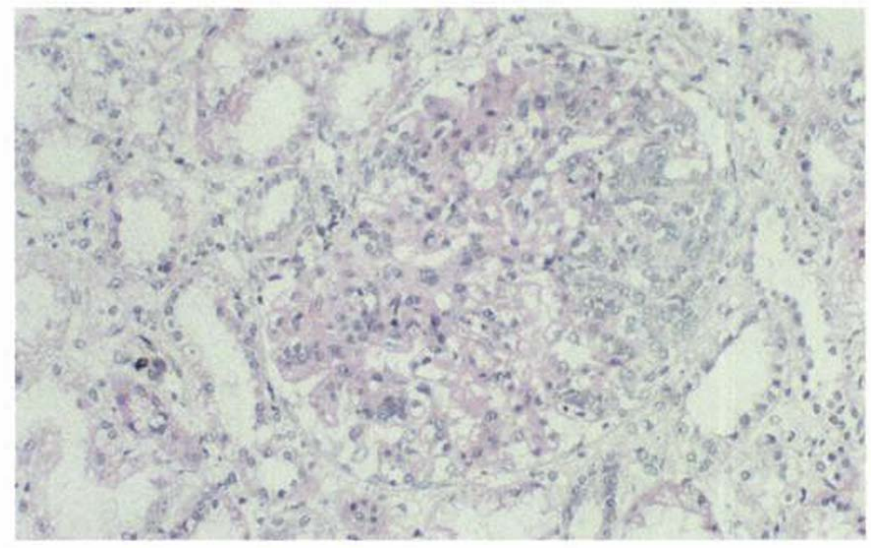

Figura I. Glomérulo con proliferación mesangial y tendencia a la lobulación. Hay proliferación endotelial (H\&Ex|0)
(0,06-0.1 g/24 horas), citoquímico de orina: $\mathrm{pH} 5,0$, densidad 1015, y hematuria microscópica positiva.

Posteriormente se practicó una biopsia renal, la cual reportó 21 glomérulos, cinco de ellos totalmente esclerosados y en los demás se apreció proliferación mesangial con tendencia a la lobulación, además de proliferación endotelial (Figura 1), atrapamiento de polimorfonucleares neutrófilos (Figura 2), engrosamiento segmentario de la membrana basal y espículas.

En el intersticio se observan abundantes histiocitos espumosos y nefritis intersticial. También se aprecia atrofiatubular focal (Figura 3).

Con la inmunofluorescencia se detectaron cuatro glomérulos, uno esclerosado. Se observó IgG puntiforme membranosa y mesangial (++++), fibrinogeno capilar

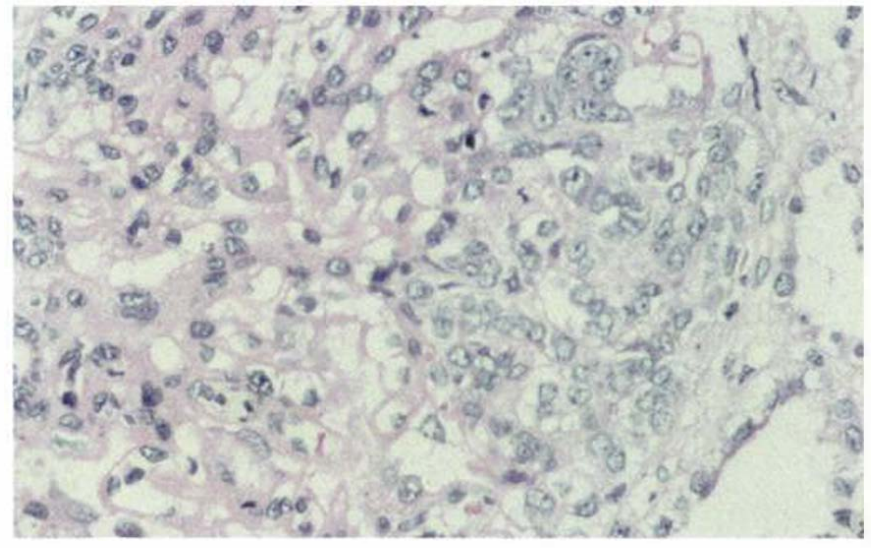

Figura 2. Atrapamiento de polimorfonucleares neutrófilos $(\mathrm{H} \& \mathrm{Ex} 40)$ 
glomerular (++), Clq puntiforme mesangial $(++), \mathrm{C} 3$ puntiforme y membranoso, C4 (-), IgM mesangial puntiforme, e IgA puntiforme membranosa y mesangial $(++++)$ (Figura 4$)$.

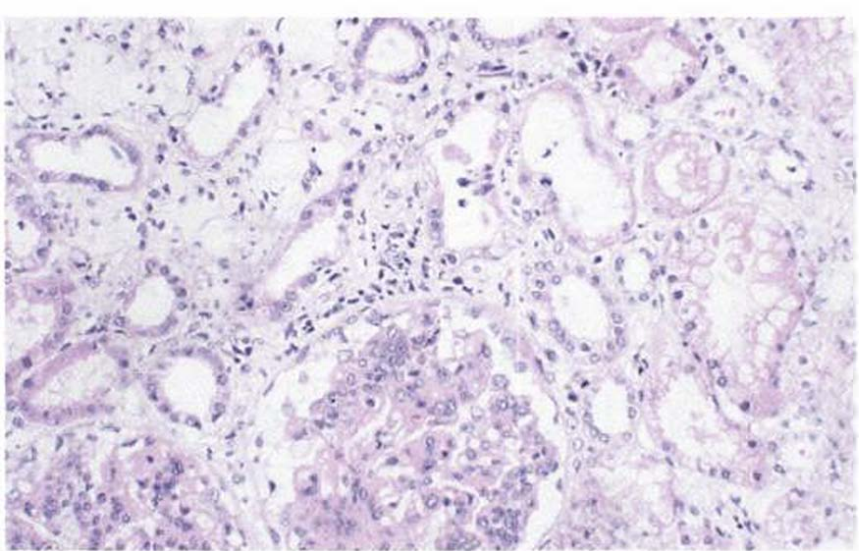

Figura 3. Nefritis intersticial, abundantes histiocitos espumosos y atrofia tubular focal $(H \& E \times 10)$

\section{Diagnóstico}

Glomerulonefritis membranoproliferativa grado histológico III/IV en fase activa, secundaria a lupus critematoso sistémico.

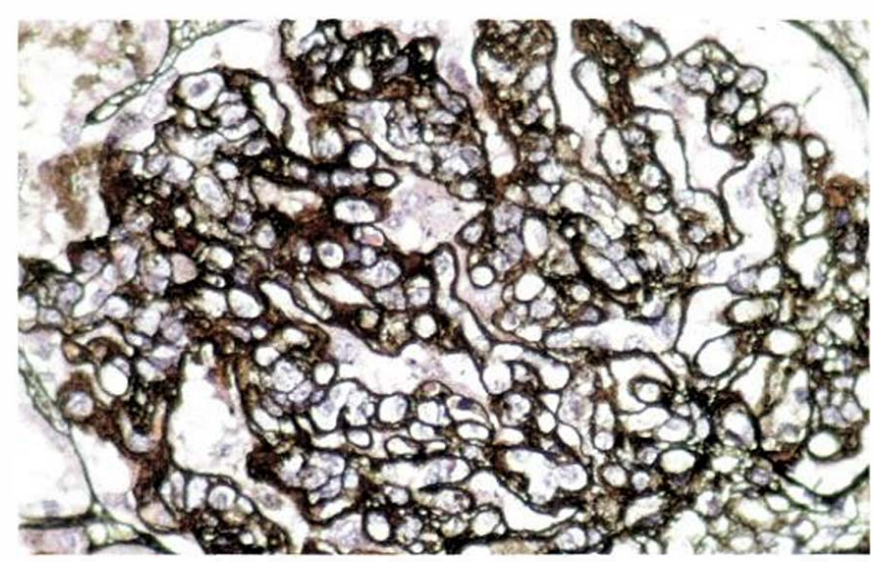

Figura 4. Coloración de PSMN, engrosamiento segmentario de la membrana basal y espiculas ( $H \& E \times 40)$. 